\title{
Weaner production with low antimicrobial usage: a descriptive study
}

Mette Fertner ${ }^{1 *}$, Anette Boklund ${ }^{1}$, Nana Dupont ${ }^{2}$, Claes Enøe $^{1}$, Helle Stege $^{2}$ and Nils Toft ${ }^{1}$

\begin{abstract}
Background: Health, productivity and antimicrobial use in the production of pigs are expected to be interrelated to some extent. Previous studies on register-based data have investigated these correlations with a subsequent large variation residing at the farm level. In order to study such farm factors in more detail we designed an elaborate interview-guide. By in-depth interviews of farmers with well-managed 7-30 kg (weaner) productions we sought to describe a set of common key-factors characterizing their management practices. Identification of such common practices could be used in follow-up projects, investigating whether identified factors really are characteristic for good-practicing famers.

Results: Eleven farms were selected for a farm visit and in-depth interview. Participating farms used less antimicrobials than the national median ( 8.2 animal daily doses/100 weaners/day), had a mortality below the national average (2.9\%) and an average daily weight gain above the national average (443 g/day). Similarities were observed among participating farms, including the sectioning of farms, use of all-in-all-out procedures with subsequent cleaning, purchasing $7 \mathrm{~kg}$ weaners from only one source, as well as active participation in management by a committed farm owner. Most farmers had a specific point of focus in their management, and were convinced that this was the reason for their success. This included; feeding, treatment strategy, refurbishment of facilities and presence in the shed.

Conclusion: According to register data, participating farms were alike; in the good league regarding use of antimicrobials, mortality and daily growth. However, on-farm interviews elucidated more heterogeneity among farmers than expected. Most of the farmers had a specific point of focus, which they considered to be crucial for their good results. These results indicate the importance of non-registerable factors, highlighting the value of qualitative study techniques in the understanding of human actions. Further studies on the effect of various farmer types are recommended.
\end{abstract}

Keywords: Swine, pig, Antibiotic use, Management, Health

\section{Background}

Several databases with information regarding farm characteristics, infection status and antimicrobial use in pig farms are available in Denmark. Previous studies have investigated how much of the between-farm variation in antimicrobial use can be attributed to risk factors present in such registers. Variation at farm level has been found to constitute $38 \%$ [1] and $40 \%$ [2] of the total variation, underlining the importance that management, housing

\footnotetext{
*Correspondence: memun@vet.dtu.dk

1 Section for Epidemiology, National Veterinary Institute, Technical University of Denmark, Bülowsvej 27, 1870 Frederiksberg C, Denmark Full list of author information is available at the end of the article
}

and the individual farmer have on the use of antimicrobials. Alternative study designs are therefore required to augment the value of register-based data.

Health, productivity and antimicrobial use at a farm are expected to be interrelated to some extent. Growthenhancing effects of antimicrobials added to the feed in sub-therapeutic concentrations are well-known [3]. Furthermore, studies on the effect of phasing out growth promoters have shown an increased incidence of gastrointestinal disorders among weaners in Denmark [4]. Sweden experienced an increased post-weaning mortality and decreased growth rate among weaners [5], which was not confirmed in Denmark [6]. 
Antimicrobials prescribed for animals are reserved for therapeutic and metaphylactic purposes in the European Union [7]. A clear link can therefore be expected between the incidence of disease and amount of antimicrobials used. Additionally, it is recognized that a number of management-related parameters, as well as variation in treatment procedures can influence the use of antimicrobials in terms of disease-preventing initiatives. Procedures for disease prevention such as sectioning [8], hygiene [8] and handling of diseased pigs [9] have been negatively correlated with the use of antimicrobials. Due to its close link with gastrointestinal disorders [10, 11], feeding is also expected to have a significant influence on the use of antimicrobials in weaners. Treatment-related factors include the farmers' perception of metaphylaxis, the ability to identify clinically-diseased pigs, and compliance with veterinary recommendations for treatment.

Denmark produces more than 30 million fattening pigs per year and is one of the world's largest exporters of pork [12]. Among the European countries producing a similar amount of pork (Germany, Spain, France, Poland, Italy and the Netherlands) [12], Denmark has the lowest rate of antimicrobial use per animal [13]. Due to the large number of animals involved, pig production accounted for $76 \%$ of the veterinary antimicrobials prescribed in Denmark in 2012 [14] and it therefore receives the main political focus in terms of antimicrobial use. Calculated as animal daily doses (ADD) the majority of prescribed antimicrobials for pigs are administered for weaners (7-30 kg pigs), and mainly for gastrointestinal disorders [15, 16]. Since 2000, the amount of prescribed antimicrobials for all farms has been recorded in a Danish national database, VetStat [17]. However, parameters such as health, productivity and management practices for $7-30 \mathrm{~kg}$ pigs are not available in any national register. Average daily weight gain and mortality may be used as objective proxies for health and productivity, since diseased pigs are expected to have a reduced weight gain and may die [18]. Yet both these parameters are solely recorded onfarm, complicating the access of these data.

Our study examines well-managed farms: farms, which have overcome the apparent paradox of having a low rate antimicrobial use, simultaneously combined with low mortality and high productivity. It was our hypothesis that well-managed 7-30 kg (weaner) productions have a set of common key-factors characterizing their management practices. Using a semi-qualitative study design, we were able to obtain a detailed knowledge about the farms and their owners. This allowed us to further elucidate issues on which it is not possible to make inferences based on the information from national databases. The objective was to identify management-related factors which, according to the farmers' own perceptions, were the primary reasons for their positive results.

\section{Methods}

Participating farms were identified by the following selection procedure. Eleven veterinarians working in pig practice and representing different geographical regions and various veterinary practices, were contacted by telephone. Of these, seven agreed to participate in the study. They were encouraged to send a list of their clients with the lowest rates of antimicrobial use, and the highest rates of health and productivity. To fulfill the selection criteria, farms had to produce $7-30 \mathrm{~kg}$ pigs and not be organic or free-range. Each veterinarian selected three to eight of their affiliated pig farms, giving a total of 46 farms. The amount of prescribed antimicrobials for each of the farms was subsequently calculated, based on VetStat data. The national database VetStat receives information on prescribed antimicrobials from feed mills, veterinarians and pharmacies [15, 17]. Data reported by pharmacies (comprising more than $98 \%$ of all antimicrobials prescribed for pigs) for the period of January 1 to December 31, 2012, were included in this study. Antimicrobials were quantified as $\operatorname{ADD}[19,20]$. The number of ADD prescribed for weaners was aggregated for each farm and divided by the number of weaner days multiplied by 100 . This standardized unit (ADD/100 weaners/day) approximates the daily percentage of weaners treated at the farm. Information on the number of weaners present in each farm was extracted from the Central Husbandry Register (CHR). The number of weaners at the farm was multiplied by 366 days (number of days in 2012) in order to compute the total number of weaner days.

Of the 46 farms initially selected, only those using less antimicrobials than the median of all Danish farms (8.2 ADD/100 weaners/day) were considered further. These 32 farms were contacted by telephone. If the farmers were interested in participating, they were required to forward their efficiency control. Efficiency control is a voluntary registration, which some farmers use to keep track of productivity. From the efficiency control, mortality and average daily weight gain were used as objective proxies for health and productivity at the farm. Only the farms with weaners with an average daily weight gain above the Danish average (443 g/day for weaners $(7-30 \mathrm{~kg}))$ and a mortality below the Danish average ${ }^{\mathrm{a}}$ (2.9\%) were included in the study [21]. Farms with new infections were excluded, due to the risk of fluctuating management practices.

Eleven farms that fulfilled the inclusion criteria agreed to participate. These farms were visited and the person in charge of the production was interviewed by the 
corresponding author. Whenever possible, farm visits were carried out alongside the monthly veterinary advisory service visit. All visits were executed during February and March 2013. Each farm visit lasted between 2 and $4 \mathrm{~h}$.

The interviews were structured in a semi open-ended manner, as described by Kvale and Brinkmann [22]. The structure of the interview was further discussed with an experienced interviewer. Due to the delicate topic of discussion, the decision was made not to record the conversations. The interview guide is available upon request. Typically, a farm visit started with a general assessment of the farm, conducted in association with the veterinarian. A thorough explorative interview was then conducted. Parameters expected to influence the antimicrobial use, health, and productivity at the farm including; employees, housing, management, hygiene, feed, biosecurity, movement of pigs and treatment procedures were addressed in the interview. Identification of these eight categories of questions were based on literature review prior to the study and subsequently presented to two specialized pig veterinarians to ensure inclusion of all important risk factors. Additionally, the farmer was asked what he/she considered the primary reasons for their successful production results. Five veterinarians were affiliated with these eleven farms and were interviewed separately. Veterinarians were first asked what they saw as the most important factors for a successful weaner production, and then they were asked to characterize their participating farms.

\section{Results and discussion}

The results presented in Table 1 represent factors which were mentioned by farmers and veterinarians as possible key-factors: SPF ${ }^{\mathrm{b}}$ infection status, management, internal biosecurity, pen hygiene between batches, feeding and treatment procedures.

In general, there was wide variation amongst farmers regarding their perception of which management parameters were the reasons for success in terms of low mortality, high daily weight gain and limited use of antimicrobials. They seemed to be divided into various categories with different points of focus, including feeding, presence in the shed, investment in facilities and treatment strategy. The choice of strategy seemed to be highly individual to each farmer. A committed farm owner, identified as a solid interest and participation in the management, characterized all participating farms. There were common factors among the interviewed farms, for example each received their $7 \mathrm{~kg}$ weaners from a single supplier, they implemented a high degree of sectioning, and a more or less consistent all-inall-out production with cleaning between batches.

\section{Farm demographics}

All farms received $7 \mathrm{~kg}$ weaners from one single supplier; either their own or a regular sow farm. The weight at entrance varied from $6.5 \mathrm{~kg}$ to $8.5 \mathrm{~kg}$. Some farmers prioritized heavy weaners at entrance (Farms 3 and 7). Nine of the participating farms participated in the voluntary SPF program, insuring that $7 \mathrm{~kg}$ weaners also originate from a SPF sow farm. The quality of $7 \mathrm{~kg}$ weaners, in terms of e.g. weight, health and growth potential is expected to be interrelated with the management at the sow farm. However, it was out of the scope for this project to go into further detail regarding management in the sow farm.

Three farms were free of all SPF-registered pathogens (Farms 4, 8 and 9), while other six SPF farms had a varying number of registered pathogens (Farms 2, 3, 5, 7, 10 and 11). Typically, the farms took into account their infection status in the management practices, in terms of sectioning and vaccine programs. SPF-registered pathogens were commonly screened, while surveillance of gastrointestinal disorders was uncommon [16].

\section{Management}

The estimated number of working hours per week varied from 1.7 to 9.3 per 1000 weaners. Farmer 8 considered presence in the shed to be crucial: "If you want a successful weaner production, you need to spend sufficient hours in the shed". Despite having old buildings, this farmer had very good results in the weaner unit. In general, newer housing is expected to facilitate good practices (such as sectioning and hygiene), enabling fewer working hours without compromising results. However, "what is crucial in the weaner production is to LOOK at the weaners, rather than at the calendar, to decide when it is time to sort them or change their feed" (Farm 8). All farmers sorted the weaners to some extent, though the strategy varied. In general, farmers sorted by size, while a small number also sorted by sex. Sorting by sex enables differentiated feeding, which may increase the meat percentage and feed conversion, and may have some effect on the prevalence of tail biting [23].

In three of the farms (Farms 2, 5 and 8), the smallest weaners $(<6 \mathrm{~kg})$ were placed in a pen with fewer penmates and given a high quality feed mixture, and milk formula or sugar water was eventually added to increase the appetite. Under these conditions, initially small weaners had a higher growth rate and were therefore able to catch up with the larger weaners during the weaner period. The majority of farmers selling $30 \mathrm{~kg}$ pigs found it important to deliver a high quality product, since: "Those $30 \mathrm{~kg}$ pigs entering that truck is my public image" (Farm 3). 
Table 1 Characteristics of 11 Danish weaner producing farms with low use of antimicrobials and high productivity

\begin{tabular}{|c|c|c|c|c|c|c|c|c|c|c|}
\hline & \multicolumn{2}{|c|}{$1^{a}\left(A\right.$ and $\left.B^{b}\right)$} & $2(A$ and $B)$ & \multicolumn{2}{|l|}{3} & \multicolumn{2}{|l|}{4} & \multicolumn{2}{|l|}{5} & 6 \\
\hline \multicolumn{11}{|l|}{ Farm demographics } \\
\hline Infection status & \multicolumn{2}{|c|}{ Unknown } & $+\mathrm{Myc}^{\mathrm{c}}$ & \multicolumn{2}{|c|}{$\begin{aligned}+ & \text { Ap }(6+12) \\
& + \text { Myc, }+ \text { PRRS }\end{aligned}$} & \multicolumn{2}{|c|}{$\begin{array}{c}\text { Free of all SPF } \\
\text { pathogens }\end{array}$} & \multicolumn{2}{|l|}{+ PRRS } & Unknown \\
\hline Biosecurity & \multicolumn{2}{|c|}{ Non-SPF } & SPF & \multicolumn{2}{|c|}{ SPF } & \multicolumn{2}{|c|}{ SPF, closed farm ${ }^{d}$} & \multicolumn{2}{|c|}{ SPF, closed farm } & Non-SPF \\
\hline $\begin{array}{l}\text { Number of } \\
7-30 \mathrm{~kg} \text { pigs }\end{array}$ & \multicolumn{2}{|c|}{$3,000+3,000$} & $2,400+1,800$ & \multicolumn{2}{|c|}{4000} & \multicolumn{2}{|c|}{1,250} & \multicolumn{2}{|c|}{2,000} & 1,800 \\
\hline Supplier & \multicolumn{2}{|c|}{ Regular sow farm } & Own sow farm & \multicolumn{2}{|c|}{ Own sow farm } & \multicolumn{2}{|c|}{ Own sow farm } & \multicolumn{2}{|l|}{ Own sow farm } & Regular sow farm \\
\hline Housed days ${ }^{e}$ & \multicolumn{2}{|c|}{$\sim 140$} & $\sim 52$ & \multicolumn{2}{|c|}{45} & \multicolumn{2}{|c|}{57} & 52 & & 139 \\
\hline $\begin{array}{l}\text { Weight }(\mathrm{kg}), \\
\text { entrance- exit }\end{array}$ & $7-s \mid$ & aughter & $6.5-32$ & $8.5-2$ & & $6.6-33$ & & $7.6-30$ & & 7.8-slaughter \\
\hline $\begin{array}{l}\mathrm{AM}^{\mathrm{f}} \text { usage } \\
\quad\left(\mathrm{ADD}_{15} / 100 / \text { day }\right)\end{array}$ & 4.16 & and 7.19 & 3.9 and 5.7 & 2.7 & & 7.37 & & 6.03 & & 0.6 \\
\hline $\begin{array}{l}\text { Average daily } \\
\text { weight gain } \\
\text { (g/day) }\end{array}$ & 800 & -825 & $\sim 500$ & 462 & & 464 & & $\sim 500$ & & 705 \\
\hline Mortality (\%) & $\sim 2$ & & $\sim 2.5$ & 1.5 & & 1.2 & & 0.7 & & 1 \\
\hline Management & & & & & & & & & & \\
\hline $\begin{array}{l}\text { Staff experience } \\
\quad \text { (years) }\end{array}$ & 2 & & 5 & 3 & & $10+$ (own & & $10+$ & & $10+$ (owner) \\
\hline $\begin{array}{l}\text { Owner participat- } \\
\text { ing }\end{array}$ & With & feeding & Daily & At $d e$ & livery & Daily & & No & & Daily \\
\hline Hours spent/week ${ }^{g}$ & 20 & $3.3 \mathrm{~h} / 1,000 \mathrm{w})$ & $7(1.7$ h/1,000w) & $37(9$ & $3 \mathrm{~h} / 1,000 \mathrm{w})$ & $11(8.8 \mathrm{~h} / 1 \mathrm{c}$ & 00w) & $15(7.5 \mathrm{~h} / 1000$ & w) & $\mathrm{NA}$ \\
\hline Sorting by & Size & and sex & Size & Size & nd sex & Size & & Size & & Size and sex \\
\hline Sorting frequency & Con & tinuously & Twice & Twic & & Twice & & At entrance & & Once \\
\hline Internal biosecurity & & & & & & & & & & \\
\hline Sectioning & High & & Not $100 \%^{h}$ & High & & High & & High (for 80\%) & & Not $100 \%$ \\
\hline Vaccinate weaners ${ }^{i}$ & PCV & & PCV2 & No & & No & & PCV2 & & NA \\
\hline Pen hygiene between & batc & hes & & & & & & & & \\
\hline Beyond washing & Disir & fection & - & Disin & ection & - & & - & & Disinfection \\
\hline Drying (days) & 2 & & $3-10$ & 6 & & $2-6$ & & $3-5$ & & 7 days \\
\hline Incl. heat (days) & 2 & & $2-3$ & 2 & & 1 & & $1-3$ & & $1-2$ \\
\hline Feeding & & & & & & & & & & \\
\hline Type & $\begin{array}{l}\text { Hom } \\
\text { we } \\
\text { ba }\end{array}$ & $\begin{array}{l}\text { e-mixed } \\
\text { t + lactic acid } \\
\text { cteria }\end{array}$ & Home-mixed dry & Purcl & ased pelleted & Home-mix & d dry & Home-mixed & wet & Home-mixed dry \\
\hline No. of mixtures & $3(7$ & -9 variations) & $2+$ extra & 2 & & 2 & & $3+$ extra & & 2 \\
\hline Zinc first 2 weeks & No & & Yes & Yes & & Yes & & Yes & & Yes \\
\hline Treatments & & & & & & & & & & \\
\hline Primary indication & Untl & hrifty & $\begin{array}{l}\text { Diarrhea at shift in } \\
\text { feed }\end{array}$ & $\begin{array}{r}\text { Diarr } \\
\text { fee }\end{array}$ & ea at shift in & $\begin{array}{l}\text { Diarrhea } 3 \\
\text { after wea }\end{array}$ & $\begin{array}{l}\text { veeks } \\
\text { hing }\end{array}$ & $\begin{array}{l}\text { (Diarrhea for th } \\
20 \% \text { not-sec } \\
\text { tioned) }\end{array}$ & & Unthrifty \\
\hline Method & $\begin{array}{l}\text { Injec } \\
\text { fe }\end{array}$ & $\begin{array}{l}\text { tion or AM in } \\
\text { d in sick pen }\end{array}$ & Group (section) & Injec & ion only & Group (per & & $\begin{array}{l}\text { Group (water i } \\
\text { feed trough) }\end{array}$ & & Injection \\
\hline$\%$ treated per & $5 \%$ & & $50 \%$ & $N A^{k}$ & & NA & & $20 \%$ & & NA \\
\hline & & 7 & 8 & & 9 & & 10 & & 11 & \\
\hline Farm demographics & & & & & & & & & & \\
\hline Infection status & & + Myc & Free of all SPF path & gens & Free of all SPF & pathogens & $+\mathrm{Myc}$ & +Ap6, +Ap12 & $+M$ & $=+$ PRRS \\
\hline Biosecurity & & SPF & SPF & & SPF & & SPF & & SPF & \\
\hline Number of $7-30 \mathrm{~kg} \mathrm{p}$ & pigs & 2,200 & 4,000 & & 4,000 & & 3,300 & & 1,72 & \\
\hline Supplier & & Own sow farm & Own sow farm & & Own sow farn & & Own & w farm & Reg & ar sow farm \\
\hline Housed days & & 44 & 50 & & 56 & & 55 & & 55 & \\
\hline
\end{tabular}


Table 1 continued

\begin{tabular}{|c|c|c|c|c|c|}
\hline & 7 & 8 & 9 & 10 & 11 \\
\hline $\begin{array}{l}\text { Weight (kg), entrance- } \\
\text { exit }\end{array}$ & $8.1-32$ & $6.6-31.7$ & $7.2-34.8$ & $7.0-33.5$ & $6.7-30.1$ \\
\hline $\begin{array}{l}\text { AM usage }\left(\mathrm{ADD}_{15} / 100 /\right. \\
\text { day) }\end{array}$ & 3.64 & 7.36 & 6.82 & 2.99 & 6.57 \\
\hline $\begin{array}{l}\text { Average daily weight gain } \\
\text { (g/day) }\end{array}$ & 576 & 497 & 498 & 486 & $426^{1}$ \\
\hline Mortality (\%) & 1.6 & 0.8 & 1.4 & 1.7 & 1.6 \\
\hline \multicolumn{6}{|l|}{ Management } \\
\hline Staff experience (years) & 6 & 1 & $5+$ & 1 & $10+$ (owner) \\
\hline Owner participating & Yes & Yes & Yes & Yes & Daily \\
\hline Hours spent/week & $7(3.2$ h/1,000w) & $37(9.3 \mathrm{~h} / 1,000 \mathrm{w})$ & NA & $14(4.2 \mathrm{~h} / 1,000 \mathrm{w})$ & $10(5.8 \mathrm{~h} / 1,000 \mathrm{w})$ \\
\hline Sorting by & Size & Size & Size & Size & Size \\
\hline Sorting frequency & Twice & Continuously & Once & Once & Once \\
\hline \multicolumn{6}{|l|}{ Internal biosecurity } \\
\hline Sectioning & High & Not $100 \%$ & Not $100 \%$ & High & Not $100 \%$ \\
\hline Vaccine weaners & No & No & No & No & NA \\
\hline \multicolumn{6}{|c|}{ Pen hygiene between batches } \\
\hline Beyond washing & Disinfection & Disinfection & Disinfection & Disinfection & - \\
\hline Drying (days) & 13 & 4 & $7-10$ & 1 & 2 \\
\hline Heating (days) & 3 & 4 & NA & 1 & 2 \\
\hline \multicolumn{6}{|l|}{ Feeding } \\
\hline Type & $\begin{array}{l}\text { (1) Purchased } \\
\text { pelleted } \\
\text { (2) Homemixed } \\
\text { wet }\end{array}$ & Purchased pelleted & Purchased pelleted & Purchased pelleted & $\begin{array}{l}\text { Purchased pel- } \\
\text { leted }\end{array}$ \\
\hline No. of mixtures & 2 & $3+$ extra & 3 & 3 & 3 \\
\hline Zinc first 2 weeks & Yes & Yes & Yes & Yes & Yes \\
\hline \multicolumn{6}{|l|}{ Treatments } \\
\hline Primary indication & $\begin{array}{l}\text { Diarrhea at shift } \\
\text { in feed }\end{array}$ & Diarrhea at shift in feed & Diarrhea at shift in feed & $\begin{array}{l}\text { Diarrhea } 4-5 \text { weeks } \\
\text { after weaning }\end{array}$ & $\begin{array}{l}\text { Diarrhea at shift } \\
\text { in feed }\end{array}$ \\
\hline Method & $\begin{array}{l}\text { Group (half } \\
\text { section) }\end{array}$ & Group (section) & Group (section) & Group (section) & Group (section) \\
\hline$\%$ treated per batch & $30-40 \%$ & $100 \%$ & $100 \%$ & $100 \%$ & $100 \%$ \\
\hline
\end{tabular}

The information presented in the table is obtained through registrations from VetStat, the farmers efficiency controls as well as semi-qualitative on-farm interviews.

a Farm No 1 and No 2 did not present their efficiency control, but reported estimated results on mortality and daily weight gain.

b $A$ and $B$ indicates that the farmer has two herds with 7-30 kg pigs.

c Presence of SPF pathogens, see endnote description.

d Closed SPF farms produce their gilts themselves and therefore do not receive pigs from other farms.

e The average number of days that a batch of weaners remains in a section.

f $A M$ Antimicrobial.

9 Labor hours spent per week is the number of weekly hours spent per 1,000 weaners, estimated by the farmer.

h "Not $100 \%$ " indicates defects in the sectioning procedures, such as: Weaners entering/leaving the housing having to pass through other sections, or pigs falling behind their batch mates being moved to another section.

i Informed by the herd owner, with the exception of farms 7, 8 and 9, where prescribed vaccines for weaners were obtained from VetStat.

j The percentage of pigs per batch being treated at least once during the weaner period, estimated by the farmer. Group treatment ("Group") was administered through the drinking water if nothing else is stated.

k Not available.

${ }^{\prime}$ Farm 11 was included, despite an average daily weight gain below $443 \mathrm{~g} /$ day, due to an entrance weight (6.7 kg) considerably lower than the national average $(7.2 \mathrm{~kg})$.

\section{Internal biosecurity and pen hygiene between batches}

All participating farms claimed to have an all-in-all-out production system. However, the extent to which this practice was managed differed between farms. Where sectioning was not practiced $100 \%$ efficiently, the design of the housing was typically regarded as a limiting factor. 
For example, a shed previously used for cattle had been transformed into a pig shed (Farm 11) and in another farm, productivity exceeded the intended housing capacity (Farm 5). Farm 5 did not observe clinical diarrhea in the majority of weaners kept under strict sectioned conditions $(80 \%)$. However, due to the inexpedient construction of the housing, $20 \%$ of the weaners were kept in a section with continuous production where diarrhea was observed and group treatment applied regularly. Sectioning [8] and improvement of housing facilities [24] has previously been found to influence the antimicrobial treatment frequency in pig farms. Additionally, a recent study by Laanen et al. [9] demonstrated that a high level of internal biosecurity (in terms of disease management) had a protective effect on the use of prophylactic group treatments, possibly due to a reduced transmission of pathogens within the farm.

In terms of hygiene between batches of pigs, it is recommended to wash, disinfect (for a minimum of $30 \mathrm{~min}$ ), and subsequently leave pens empty for at least 2 weeks in order to reduce the transmission of Lawsonia intracellularis [25]. None of the participating farms were left idle for this time period, possibly due to the associated loss of income or lack of shed capacity. Nielsen et al. [8] found that the risk of antimicrobial group treatment in finisher farms increased by a factor of four, when the housing was never cleaned. Likewise, Laanen et al. [9], identified a positive correlation between cleaning and daily weight gain, possibly due to the reduction of gastrointestinal disorders.

\section{Feeding}

Good feeding practices may contribute to a healthy gastrointestinal microbiota, preventing diarrhea. More than half of the participating farms typically experienced diarrhea at shifts in feed (Farms 2, 3, 7, 8, 9 and 11), while only two farms did not observe diarrhea as the main clinical indication for treatment (Farms 1 and 6). Both mentioned the feeding as the reason: "Diarrhea? No I adjust the feeding" (Farmer 6). Whenever feces softened, they would decrease the grind of the feed slightly (Farm 6), or add a lactic acid bacteria starting culture (Farm 1). Farm 1 also added lactic acid bacteria starter culture in the feed for newly-arrived weaners. This is in accordance with prior scientific studies, demonstrating how probiotic bacteria, Bifidobacterium lactis Bb12 and Lactobacillus rhamnosus, may inhibit the adhesion of Salmonella sp., Clostridium sp. and Eschericia coli to the intestinal mucosa [26].

\section{Treatment procedures}

Farmers were asked to estimate the percentage of weaners treated in each batch, resulting in estimated treatment percentages ranging between 5 and 100\%. Based on veterinary directions, the farmer chose when to initiate treatment, how to treat, the duration of treatment and what dose to use. All four parameters are highly dependent on the owner setting the standards of the farm, as well as the person in charge of the daily routines. The initiation of treatment depends on the ability to detect diseased animals, as well as the willingness of the farmer to tolerate the clinical signs. As the owner of Farm 3 stated: "When you choose to have a low use of antimicrobials, you need to accept a certain level of diarrhea among your weaners". This farmer rejected group treatment as "It's a principle?" In his experience, if the clinical diarrhea did not affect the general condition of the weaners they would recover without treatment. However, an "injection-only-strategy" has a considerable influence on the workload and subsequent labor costs, and can therefore be followed only by farms with the available resources. However, it can be argued that a high number of injections may stress the pigs and subsequently reduce welfare.

According to farmer No 3, the ability to detect diseased pigs and to initiate treatment at the optimal time is highly dependent on the person in charge of the daily routines. "Some have the talent, while others will never learn" (Farm 3). Hence, a person, which by the farmer may be characterized as talented, may use more antimicrobials in striving towards higher levels of health, welfare and productivity among the pigs. On the other hand, initiating early treatment may reduce transmission of disease and thus decrease the total amount of antimicrobials needed. However, some of the specialized pig veterinarians contacted during the initial study confirmed that farms with the highest level of health and productivity were not necessarily those using the lowest amount of antimicrobials.

More than half the participating farms administered antimicrobials in smaller units than on the section level (Farms 1, 3, 4, 5, 6, 7). One farm had two water pipes per section, enabling treatment of half a section at a time (Farm 7), while another had installed a medicine dispenser on each pen (Farm 4). Group treatment, where antimicrobials are administered through feed or water to a group of pigs, is widespread in pig production [27, 28]. Antimicrobials added to water are administered through a dispenser coupled to the water pipe. Hence, the configuration of the water pipes and/or dispenser types may have an impact on the number of treated animals at the farm, which may lead to a higher consumption of antimicrobials the larger unit each dispenser relates to.

Results from this study revealed some incongruence between recorded data and reality. In Farm 1 only 5\% of the pigs received treatment. Despite this low treatment frequency, the apparent antimicrobial use as stated in VetStat was higher than expected (4.16 and 7.19), 
compared to farms treating 20\% (6.03, Farm 5) and 50\% (3.9 and 5.7, Farm 2) of their pigs. Pigs in Farm 1 stayed in the same section from a weight of $7 \mathrm{~kg}$ until slaughter. Antimicrobials were mainly being prescribed for weaners, but essentially administered after the pig had exceeded $30 \mathrm{~kg}$ of weight. This account was confirmed by the amount of antimicrobials being prescribed for finishers, which was close to zero. The treatment of a pig of $45 \mathrm{~kg}$ accounts for one ADD/100 finishers/day, but three $\mathrm{ADD} / 100$ weaners/day. This is based on the calculation of ADD, using $15 \mathrm{~kg}$ as a measure for a standard weaner and $50 \mathrm{~kg}$ as a measure for a standard finisher. As the antimicrobials were prescribed for weaners but used for finishers, the actual amount of ADDs for weaners at Farm 1 is expected to be markedly lower than stated in Table 1. Observations like this, elucidates the incongruence existing between VetStat data and use of antimicrobials in real life. Hence, in farms housing more age groups, it is essential for the veterinarian to be observant towards which age group of pigs actually is treated. When evaluating the antimicrobial use as ADD/100 pig/ day, it is important to keep in mind that it is a statistical measure created to enable comparison of the relative consumption between farms, and is not necessarily a measure of the actual amount of antimicrobials used at the farm [19].

The impact on antimicrobial use of some of the factors discussed above, are supported by a currently unpublished study performed by Dupont et al., which investigates key factors which are related to a reduced use of antimicrobials. Dupont et al. found vaccination strategy and treatment method (smaller dosage, fewer group treatments, shorter treatment duration and changes in antimicrobial product) to be pointed out by farmers and veterinarians as the most important reasons for a decreased use of antimicrobials. Additionally, changes in feeding and increased compliance towards all-in-all-out procedures were mentioned.

\section{Conclusions}

According to register data, participating farms were alike; low use of antimicrobials, mortality and high daily growth. However, on-farm interviews elucidated more heterogeneity among farmers than expected. Most of the farmers had a specific point of focus which they considered to be crucial for their good results. Points of focus mentioned by the farmers included feeding, treatment strategy, refurbishment of facilities and presence in the shed. These results indicate the importance of studies going beyond register data. Qualitative study techniques are needed striving towards a better understanding of the actions taken behind data. Further studies on the effect of farmer types are recommended.

\section{Endnotes}

${ }^{a}$ Averages of daily weight gain and mortality are calculated as national averages of efficiency-control data from a representative sample of farms. The parameters are calculated as annual averages based on the number of inserted pigs.

${ }^{b}$ SPF, or Specific Pathogen Free farms, is a trademark of pig farms which ensures a certain level of external biosecurity through the restriction of entering visitors, equipment, feed and pigs. Hence, entering pigs need to come from another SPF farm with identical or higher health status [29]. Farms can be free from all (SPFX-) or some of the following: Porcine Reproductive- and Respiratory Syndrome (PRRS), Actinobacillus pleuropneumoniae (Ap), Mycoplasma hyopneumoniae (Myc), haemolytic Serpulina hyodysenteriae (Dys), toxin-producing Pasteurella multocida (Nys), Haematopinus suis and Sarcoptes Scabiei var. suis. If diagnosed with a disease, the abbreviation appertaining the pathogen is added as e.g. +Ap2 (presence of Actinobacillus pleuropneumoniae, serotype 2).

\section{Author's contributions}

MF designed the interview-guide, contacted participating farmers and veterinarians, carried out the on-farm interviews and drafted the manuscript under close supervision by NT and AB. ND participated in the design of the interview-guide, practicalities prior to farm visits an assisted in the data management. CE and HS participated in the design of the study. All authors have read and approved the final manuscript.

\section{Author details}

${ }^{1}$ Section for Epidemiology, National Veterinary Institute, Technical University of Denmark, Bülowsvej 27, 1870 Frederiksberg C, Denmark. ${ }^{2}$ Department of Large Animal Sciences, Faculty of Health and Medical Sciences, University of Copenhagen, Grønnegaardsvej 2, 1870 Frederiksberg C, Denmark.

\section{Acknowledgements}

We gratefully acknowledge the participation of farmers and veterinarians. Without their participation, this study would not have been possible.

Compliance with ethical guidelines

Competing interests

The authors declare that they have no competing interests.

Received: 3 March 2015 Accepted: 3 July 2015

Published online: 17 July 2015

\section{References}

1. Vigre H, Dohoo IR, Stryhn H, Jensen VF (2010) Use of register data to assess the association between use of antimicrobials and outbreak of Postweaning Multisystemic Wasting Syndrome (PMWS) in Danish pig herds. Prev Vet Med. 93:98-109

2. Hybschmann GK, Ersboll AK, Vigre H, Baadsgaard NP, Houe H (2011) Herdlevel risk factors for antimicrobial demanding gastrointestinal diseases in Danish herds with finisher pigs: a register-based study. Prev Vet Med 98:190-197

3. Martel JL, Tardy F, Sanders P, Boisseau J (2001) New trends in regulatory rules and surveillance of antimicrobial resistance in bacteria of animal origin. Vet Res 32:381-392 
4. Grave K, Jensen VF, Odensvik K, Wierup M, Bangen M (2006) Usage of veterinary therapeutic antimicrobials in Denmark, Norway and Sweden following termination of antimicrobial growth promoter use. Prev Vet Med 75:123-132

5. Wierup M (2001) The Swedish experience of the 1986 year ban of antimicrobial growth promoters, with special reference to animal health, disease prevention, productivity, and usage of antimicrobials. Microb Drug Resist 7:183-190

6. Aarestrup FM, Jensen VF, Emborg HD, Jacobsen E, Wegener HC (2010) Changes in the use of antimicrobials and the effects on productivity of swine farms in Denmark. Am J Vet Res 71(7):726-733

7. Schwarz S, Kehrenberg C, Walsh TR (2001) Use of antimicrobial agents in veterinary medicine and food animal production. Int J Antimicrob Agents 17:431-437

8. Nielsen EO, Hassing AG, Wachmann H, Baekbo P, Petersen HH et al (2002) Use of antibiotics in Danish porker-production. Risk factors associated with high frequency of treatment [In Danish]. Dansk Vettidsskri 85:6-13

9. Laanen M, Persoons D, Ribbens S, de JE, Callens B, Strubbe M, Maes D, Dewulf J (2013) Relationship between biosecurity and production/antimicrobial treatment characteristics in pig herds. Vet J. 198:508-512

10. Heo JM, Kim JC, Hansen CF, Mullan BP, Hampson DJ, Maribo H et al (2010) Effect of dietary protein level and zinc oxide supplementation on the incidence of post-weaning diarrhoea in weaner pigs challenged with an enterotoxinogenic strain of Escherichia coli. Livestock Sci 133:210-213

11. Kim JC, Hansen CF, Mullan BP, Pluske JR (2012) Nutrition and pathology of weaner pigs: nutritional strategies to support barrier function in the gastrointestinal tract. Anim Feed Sci Tech 173:3-16

12. Danish Agriculture and Food Council (2015) Statistics 2013, pigmeat. 2014. https://www.lf.dk/ /media/If/Tal\%20og\%20analyser/Aarsstatistikker/Statistik\%20svin/2013/LF_STATISTICS_PIGMEAT_2013_A5_UK_ WEB_2.ashx. Accessed 27 Feb 2015

13. European Medicines Agency (2014) Sales of veterinary antimicrobial agents in 26 EU/EEA countries in 2012. 2014:4. http://www.ema.europa. eu/docs/en_GB/document_library/Report/2014/10/WC500175671.pdf. Accessed 29 May 2015

14. Danmap (2012) Use of antimicrobial agents and occurrence of antimicrobial resistance in bacteria from food animals, food and in humans in Denmark. 2013. http://www.danmap.org/Downloads/ /media/Projekt\%20 sites/Danmap/DANMAP\%20reports/DANMAP\%202012/Danmap_2012. ashx. Accessed 27 Feb 2015

15. Jensen VF, Emborg HD, Aarestrup FM (2012) Indications and patterns of therapeutic use of antimicrobial agents in the Danish pig production from 2002 to 2008. J Vet Pharmacol Ther 35:33-46
16. Pedersen KS (2012) Weanerdiarrhoea. Clinical, pathological and microbiological findings in clinical weanerdiarrhoea [In Danish]. Dansk Vet Tidsskr 95:18-22

17. Stege H, Bager F, Jacobsen E, Thougaard A (2003) VETSTAT-the Danish system for surveillance of the veterinary use of drugs for production animals. Prev Vet Med 57:105-115

18. Johansen M, Alban L, Kjaersgaard HD, Baekbo P (2004) Factors associated with suckling piglet average daily gain. Prev Vet Med. 63:91-102

19. Jensen VF, Jacobsen E, Bager F (2004) Veterinary antimicrobial-usage statistics based on standardized measures of dosage. Prev Vet Med 64:201-215

20. Danmap (2009) Use of antimicrobial agents and occurrence of antimicrobial resistance in bacteria from food animals, foods and humans in Denmark. 2010. http://www.danmap.org/ /media/Projekt\%20sites/Danmap/DANMAP\%20reports/Danmap_2009.ashx. Accessed 27 Feb 2015

21. Vinther J (2012) National average on productivity in the pig production 2011 [In Danish]. http://vsp.If.dk/Publikationer/Kilder/Notater/2012/1212. aspx. Accessed 27 Feb 2015

22. Kvale S, Brinkmann S (2009) Interview, 2nd edn. Hans Reitzels Forlag, København

23. Steinmetz HV, Pedersen ML (2009) Segregation of sexes in the pig barn and the effect of tail biting [In Danish]. http://vsp.lf.dk/Publikationer/ Kilder/lu_medd/2009/845.aspx?full=1. Accessed 27 Feb 2015

24. Coyne LA, Pinchbeck GL, Williams NJ, Smith RF, Dawson S, Pearson RB et al (2014) Understanding antimicrobial use and prescribing behaviours by pig veterinary surgeons and farmers: a qualitative study. Vet Rec. doi:10.1136/vr.102686

25. Collins A, Love R, Pozo J, Smith SH, McOrist S (2000) Studies on the ex vivo survival of Lawsonia intracellularis. Swine Health Prod 8:211-215

26. Collado MC, Grzeskowiak L, Salminen S (2007) Probiotic strains and their combination inhibit in vitro adhesion of pathogens to pig intestinal mucosa. Curr Microbiol 55:260-265

27. Dunlop RH, McEwen SA, Meek AH, Black WD, Clarke RC, Friendship RM (1997) Individual and group antimicrobial usage rates on 34 farrow-tofinish swine farms in Ontario Canada. Prev Vet Med 34:247-264

28. Varga C, Rajic A, McFall ME, Reid-Smith RJ, Deckert AE, Checkley SL et al (2009) Associations between reported on-farm antimicrobial use practices and observed antimicrobial resistance in generic fecal Escherichia coli isolated from Alberta finishing swine farms. Prev Vet Med. 88:185-192

29. Anonymous (2015) SPF-Health regulations for SPF-herds [In Danish]. http://spfsus.dk/ /media/system/8/6/0/b/860b1f1ab40810ca19e cba9249123569/sundhedsregler\%20010515.ashx. Accessed 28 May 2015

\section{Submit your next manuscript to BioMed Central and take full advantage of:}

- Convenient online submission

- Thorough peer review

- No space constraints or color figure charges

- Immediate publication on acceptance

- Inclusion in PubMed, CAS, Scopus and Google Scholar

- Research which is freely available for redistribution

Submit your manuscript at 